\title{
SYNTHESIS AND OPTICAL PROPERTIES OF THE NOVEL HO(5-SSA), (5-SSA = 5-SULFOSALICYLIC ACID) CAGE STRUCTURE
}

\author{
Adem DÖNMEZ* \\ Department of Physics, Faculty of Science, Muğla Sıtkı Koçman University, Turkey, adonmez@mu.edu.tr \\ (iD) https://orcid.org/0000-0002-9773-0493
}

Received: 12.02.2018, Accepted: 07.06.2018

*Corresponding author

Research Article

DOI: $10.22531 /$ muglajsci.423816

\begin{abstract}
In recent years, intensive studies have been made on metal-organic frameworks (MOFs) which is kind of spongy structures having excellent original architectures formed by ligands in organic forms and metal centers classified as binders. The main reason for this condensation is due to the great huge potential for such materials to be used in many technological application areas such as sensors, gas storage, photo-catalysis, organic light emitting diodes (OLEDs), solar cells (SCs) and luminescent emitting devices. The properties of the metal-organic frameworks depend on the selected organic ligands and metal ions. Therefore, new research and technology development ( $R-T-G)$ fields can be discovered with these materials that can be originally synthesized. In this work, Ho(III)-based metal-organic framework (Ho-MOF; [Ho(5-SSA)], 5-SSA = 5sulfosalicylic acid) was synthesized by hydrothermal method. The structural characterization has been made by powder $X$ ray diffraction, a room temperature solid-state UV and FT-IR spectroscopy. In addition, the solid-state photoluminescence measurements have been taken at room temperature in the UV-visible and near-infrared region (NIR) and the energy transfer mechanism from 5-SSA ligand to the $\mathrm{Ho}^{+3}$ ion is investigated in detail. Under the excitation of UV light (at $349 \mathrm{~nm}$ ), 5-SSA ligand exhibited a broad navy-blue emission while its Ho-MOF complex exhibited several characteristic emissions of the $\mathrm{Ho}^{+3}$ ion in the UV-Visible and NIR region. The excellent luminescent performances make this compound very good candidate for efficient luminescence materials.

Keywords: Luminescence, Metal-Organic Frameworks, Holmium
\end{abstract}

\section{ÖZGÜN Ho(5-SSA), (5-SSA = 5-SÜLFOSALİSİLİK ASİT) KAFES YAPISININ SENTEZLENMESI VE OPTIKKSEL ÖZELLİKLERI}

\section{$\ddot{0} \mathbf{z}$}

Birleştirici olarak adlandırılan organik yapıdaki ligandlar ile bağlayıcı olarak sınıflandırılan metal merkezlerin oluşturdukları mükemmel özgün mimariye sahip olan süngerimsi yapılar diğer bir deyişle Metal organik çerçeveler (MOÇ) üzerinde son yıllarda oldukça yoğun çalışmalar yapılmaktadır. Bu yoğunlaşmanın başlıca nedeni bu tür malzemelerin sensörler, gaz depolama, foto-katalizörler, organik ışık yayan diyotlar (OLED), güneş hücreleri (SC) ve lüminesans yayabilen aygıtlar gibi birçok teknolojik uygulama alanlarında kullanılabilme potansiyelinin yüksek olmasından ötürüdür. Metal organik çerçevelerin özellikleri, seçilen organik ligandlara ve metal iyonlarına bağlıdır. Dolayısıyla özgün olarak sentezlenebilen bu kristal malzemeler ile yeni araştırma ve teknoloji geliştirme (Ar-Te-Ge) alanları keşfedilebilmektedir. Bu çalışmada, Ho(III)-tabanlı metal-organik çerçevesi (Ho-MOÇ; [Ho(5-SSA)], 5-SSA = 5-Sülfosalisilik asit) hidrotermal metot ile sentezlenmiştir. Toz kristal X-ışını kırınımı, oda sıcaklığında katı-hal UV ve FT-IR spektroskopisi teknikleri yardımıla yapısal karakterizasyonu yapılmıștır. Buna ek olarak, oda sıcaklığında görünür ve yakın kızıl ötesi (NIR) bölgede katı hal fotolüminesans ölçümleri alınmış ve 5-SSA ligandından Ho+3 iyonuna olan enerji transfer mekanizması detaylı bir şekilde incelenmiştir. UV ışınım altında (349 nm'de), 5-SSA ligandı geniş bir lacivert renginde yayılım sergilerken, Ho-MOÇ kompleksi UV-Görünür ve NIR bölgesinde Ho ${ }^{+3}$ iyonunun çeşitli karakteristik emisyonlarını sergilemiştir. Mükemmel ışıldama performansları, bu bileşiği yüksek verimli ışınım veren malzemeler için çok iyi bir aday haline getirmektedir.

Anahtar Kelimeler: Lüminesans, Metal-Organik Çerçeveler, Holmiyum

Cite

Dönmez, A., (2018). "Synthesis and optical properties of the novel ho(5-SSA), (5-SSA = 5-sulfosalicylic acid) cage structure", Mugla Journal of Science and Technology, 4(1), 116-122.

\section{Introduction}

Metal-organic frameworks (MOFs) which are Nanodimensional materials have porous structures [1-5].
Research interest in metal-organic frameworks (MOFs) is a relatively young and dynamic research field from the beginning of the $21^{\text {st }}$ century, when compared to other scientific fields, is one of the most important candidates 
for the interdisciplinary research [6-10]. MOFs which consist of the rare earth elements have some interesting magnetic and luminescence properties [11-17]. These materials also have high hydrogen storage, gas adsorption, and separation, photo-catalysis, and sensor properties [2,18,19]. The materials designed with organic ligands and lanthanide ions which have a porous structure are called lanthanide metal-organic frameworks (Ln-MOFs). The design and synthesis of the 1D, 2D or 3D Ln-MOFs can be accomplished by intelligently choosing the appropriate combination of the binder lanthanide ions and organic ligands [20-24]. LnMOFs gain high absorption capacities through organic based chromophores.

One of the most commonly used methods of synthesis of Ln-MOFs is the hydrothermal technique, which is less harmful to the environment. This technique is an ideal method for the synthesis of solid-state compounds such as on organic hybrid, inorganic hybrid, supramolecular and so on. The hydrothermal technique is defined as a heterogeneous reaction in the presence of aqueous solvents or mineralizers under high pressure and temperature to dissolve and crystallize insoluble materials under normal conditions [25-27]. Nowadays, hydrothermal technique is used extensively in the synthesis of the metal complexes, polymers and ceramics with increasing demands on the Nano-structures.

Recent advances in Nano-technology have attracted considerable interest in the Holmium-based metalorganic frameworks (Ho-MOFs) which have interesting structural and luminescent properties [28,29]. Ho-MOFs which are frequently used in luminescent-based material designs is one of the prominent candidates in the development of the multifunctional materials. Holmium complexes find the usage in telecommunication, photonics and biological applications as infrared radiation emitting materials [30-33].

In this work, new Ho-MOF complex was synthesized by hydrothermal method. The structural characterization has been made by powder X-ray diffraction, a room temperature solid-state UV and FT-IR and photoluminescence spectroscopy.

\section{Material and Method}

The chemical reagents and solvents used in this study were obtained commercially from Sigma-Aldrich and Merck and used without any purification. Powder XRD pattern of the organic ligand (5-SSA) and the complex (Ho-MOF) were measured using Philips X'Pert Pro powder diffractometer with the $\mathrm{Cu}-\mathrm{K} \alpha$ radiation. The IR and UV spectra of these materials were measured at room temperature in solid state condition using PerkinElmer Spectrum 65 FT-IR spectrometer and Ocean Optics Maya 2000Pro spectrometer, respectively. Photoluminescence measurements were made at room temperature with a Perkin Elmer LS 55 molecular fluorimeters and Andor Solis SR 500i-BL model spectrometer equipped with a triple grating and used an air-cooled CCD camera as a detector. Spectra-Physics model Nd-YLF (349 $\mathrm{nm}$ ) laser was used as an excitation source for emission spectra. Each laser pulse has a pulse width of $5 \mathrm{~ns}$ and $1.33 \mathrm{~mJ}$ of energy per pulse.

\subsection{Preparation of the Ho-MOF: Ho(5-SSA)], 5-SSA = 5-Sulfosalicylic Acid}

The hydrothermal technique has been used for the synthesis of the Ho-MOF. In this technique, the organic ligand 5-sulfosalicylic acid ( $0.1 \mathrm{mmol}, 0.0254 \mathrm{~g})$ which is indicated in Fig. 1. was dissolved in $10 \mathrm{~mL}$ distilled water by heating to the boiling point. Then the $\mathrm{Ho}\left(\mathrm{NO}_{3}\right)_{3} .5 \mathrm{H}_{2} \mathrm{O}$ ( $0.1 \mathrm{mmol}, 0.0441 \mathrm{~g}$ ) was added to the former solution and stirred for 30 minutes with the magnetic stirrer. During the whole process, the $\mathrm{pH}$ values of this solution have been observed. The final $\mathrm{pH}$ value of this reaction media are around 4.0. This mixture was sealed into the acid reactor equipped with a Teflon liner which has a 45 $\mathrm{mL}$ volume and heated $140{ }^{\circ} \mathrm{C}$ for 5 days. After 5 days, the reactant mixture was slowly cooled to the room temperature. The obtained crystals were separated by filtration paper and washed with distilled water.

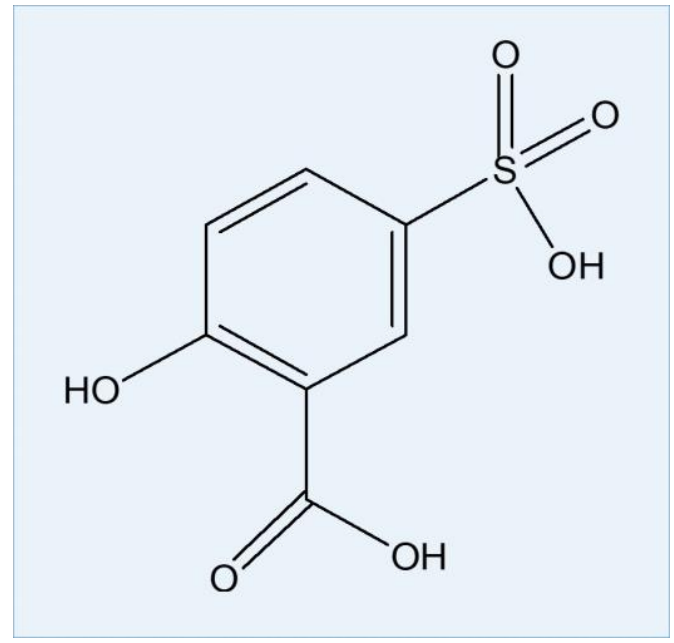

Figure 1. Schematic representation of the 5-SSA organic ligand.

\section{Research Findings}

\subsection{The Powder X-ray Diffraction of the Ho-MOF}

Before taking into consideration about some spectroscopic and luminescence analyses, the intensity data of the Ho-MOF obtained from powder X-ray measurement (PXRD) was compared with a similar single crystal structure synthesized with the same ligand in the literature using the Mercury software [34]. The data obtained from the powder X-ray measurement is called "measured" and the data obtained from the literature by using Mercury program is called "calculated" as shown in Fig. 2. The PXRD results showed that the peak positions match well with those from the simulated PXRD patterns on the basis of single-crystal structure data, indicating reasonable crystalline phase purity (Fig. 2). 


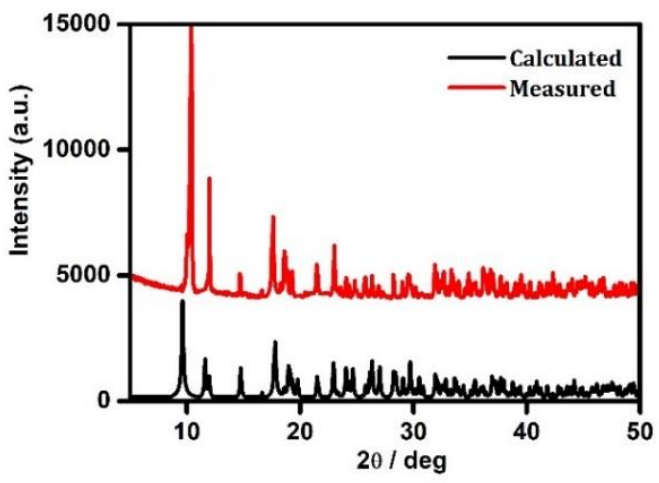

Figure 2. X-ray powder diffraction patterns from the HoMOF complex.

\subsection{The FT-IR Spectra of the Ho-MOF}

To be able to find out bond vibration process of the structures, the IR spectra of Ho-MOF and its free ligand (5-SSA) have been measured and their spectra have been compared with each other. As can be seen in Fig. 3., the peaks observed in the IR spectra of the Ho-MOF and 5SSA are in almost similar regions except a few of them. It has been overserved that there is a strong broad vibration peak which may be due to the $v(\mathrm{O}-\mathrm{H})$ stretching vibration of the water molecules at $3353 \mathrm{~cm}^{-1}$ for the HoMOF complex $[28,29,34,35]$. The absence of strong vibration peak in the complex, while it has been observing in the 3067-1662 $\mathrm{cm}^{-1}$ region for 5-SSA organic ligand, can be interpreted as the depletion of the protons of the $\mathrm{SO}_{3} \mathrm{H}$ and $\mathrm{COOH}$ groups $[28,29,34]$. The strong vibration peaks are originated from carboxylate groups of $v_{\text {as }}(\mathrm{COO})$ at $1608 \mathrm{~cm}^{-1}$ and $v_{\mathrm{s}}(\mathrm{COO})$ at 1506 $1330 \mathrm{~cm}^{-1}$ region in the Ho-MOF complex. This case may suggest that the carboxylate groups are coordinated with the holmium ions in the chelating mode [36-38]. In addition, there are some characteristic peaks in the region of $1255-1048 \mathrm{~cm}^{-1}$. The sulfonate groups which are $v(\mathrm{~S}-\mathrm{O})$ and $v(\mathrm{C}-\mathrm{S})$ may be responsible for these observed peaks $[29,39,40]$. All of these observed peaks shift towards the lower wave number values with very little difference in the IR spectrum of the 5-SSA ligand. The peaks in the band of $917-670 \mathrm{~cm}^{-1}$ are caused by $\mathrm{O}-\mathrm{Ho}-\mathrm{O}$ and $\mathrm{Ho}-\mathrm{O}$ stretching vibrations [41].

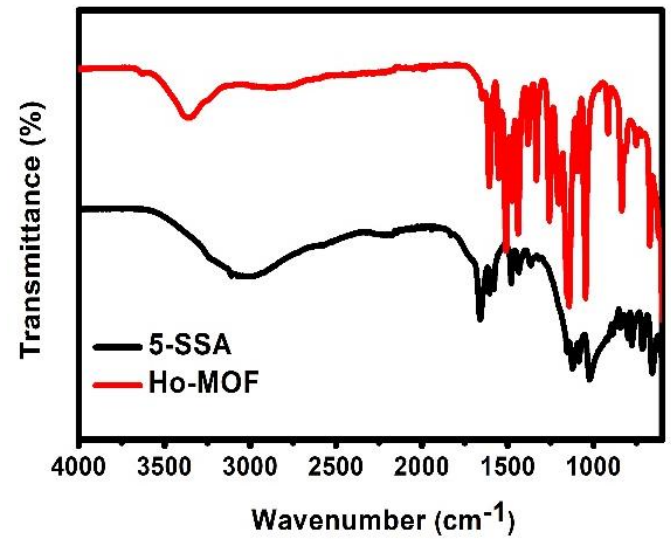

Figure 3. The IR spectra of the Ho-MOF complex and 5SSA organic ligand.

\subsection{The Solid-State UV-Vis spectra of the Ho-MOF}

The UV-Vis spectroscopy method is a more powerful technique which could give an idea about the electronic transition of the molecular structures. The solid-state UV-Vis spectra of Ho-MOF complex and 5-SSA ligand have been taken individually at room temperature and the obtained results were compared by each other as shown in Fig. 4.

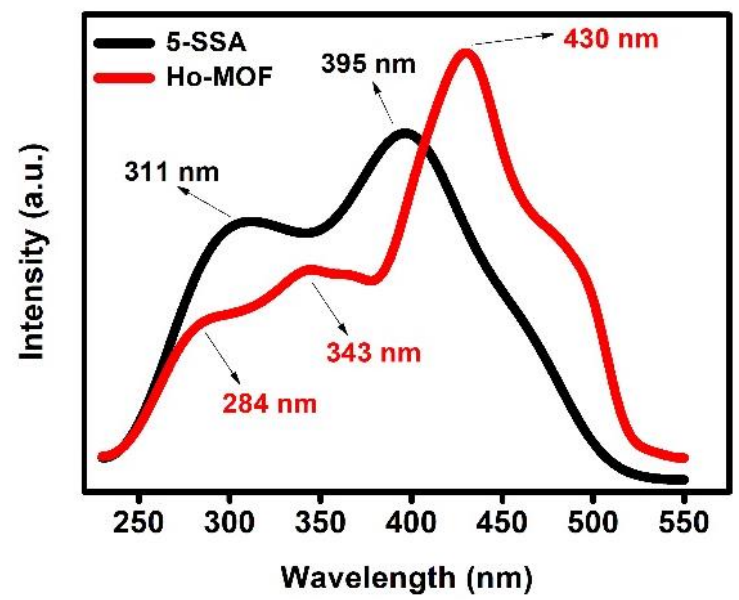

Figure 4. The Solid-state UV-Vis spectra of the Ho-MOF complex and 5-SSA organic ligand.

The first noticeable aspect from UV-Vis spectra is that both spectra have different broad absorption peaks. The maximum values of these absorption peaks are at $311 \mathrm{~nm}$ and $395 \mathrm{~nm}$ for the ligand 5-SSA and $284 \mathrm{~nm}, 343 \mathrm{~nm}$ and $430 \mathrm{~nm}$ for the Ho-MOF complex. The dominant absorption bands might be assigned to $\pi-\pi^{*}$ or $n-\pi^{*}$ transition of the 5-SSA ligand. It can be concluded that the red shifting of the absorption band in the UV-Vis spectra of Ho-MOF complex reminds the Holmium ion coordination with the 5-SSA ligand $[28,41,42]$.

\subsection{The Solid State Photoluminescence Properties of the Ho-MOF}

One of the best spectroscopy technique for uncovering the energy transfer mechanism of the metal-organic frameworks is the photoluminescence measurement method. The solid-state photoluminescence measurements were taken for the 5-SSA ligand and the Ho-MOF complex in the visible and near-infrared region at room temperature under the excitation at $349 \mathrm{~nm}$. The PL spectrum of the 5-SSA ligand has a broad navy-blue emission peak upon the excitation at $\lambda_{\max }=349 \mathrm{~nm}$ as indicated in Fig. 5. The maxima of this emission spectrum are located at $466 \mathrm{~nm}$. One can interpret that the $n \rightarrow \pi^{*}$ or $\pi \rightarrow \pi^{*}$ electronic transition (ILCT) causes of this emission band $[41,43]$. 


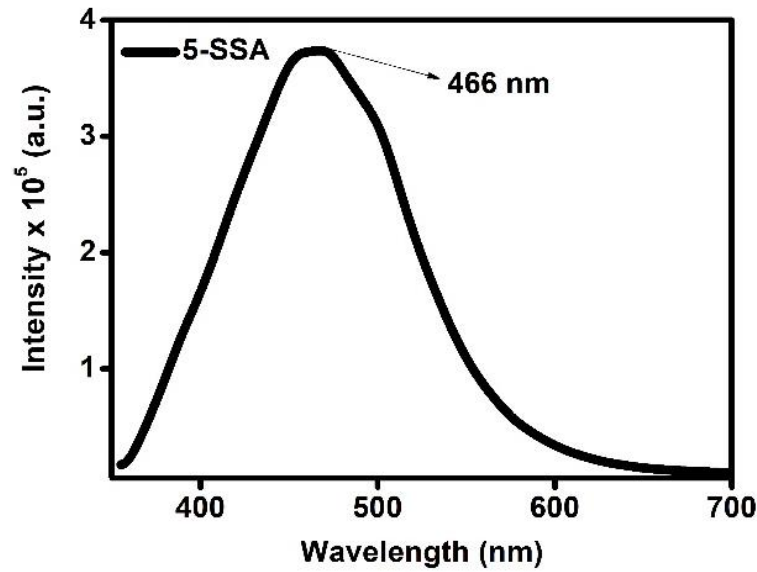

Figure 5. PL spectrum of the 5-SSA free ligand under the excitation at $349 \mathrm{~nm}$ at room temperature.

The lanthanide-based materials may have very strong sharp emission bands due to the f-f transitions of the lanthanide ions. When the Ho-MOF complex is excited at $349 \mathrm{~nm}$, several characteristic emission bands of the $\mathrm{Ho}^{+3}$ ion have popped out in the visible and NIR region regions as seen in Fig. 6. and Fig. 7.

The sharp emission bands at $410 \mathrm{~nm}\left({ }^{5} \mathrm{G}_{4} \rightarrow{ }^{5} \mathrm{I} 8\right), 428 \mathrm{~nm}$ $\left({ }^{5} \mathrm{G}_{5} \rightarrow{ }^{5} \mathrm{I}_{8}\right)$ and $648 \mathrm{~nm}\left({ }^{5} \mathrm{~F}_{5} \rightarrow{ }^{5} \mathrm{I}_{8}\right)$ are much more intense than the others. The other emission peaks which are weaker as an intensively might be attributed to the ${ }^{5} \mathrm{G}_{6} \rightarrow$ ${ }^{5} \mathrm{I}_{8}$ and ${ }^{5} \mathrm{~F}_{3} \rightarrow{ }^{5} \mathrm{I}_{8}$ transitions for $463 \mathrm{~nm}$ and $536 \mathrm{~nm}$ in the visible region. In the NIR region, three weak emission bands at $792 \mathrm{~nm}, 1139 \mathrm{~nm}$, and $1470 \mathrm{~nm}$ are attributed to the f-f transition ${ }^{5} \mathrm{~S}_{2}+{ }^{5} \mathrm{~F}_{4} \rightarrow{ }^{5} \mathrm{I}_{7},{ }^{5} \mathrm{I}_{6} \rightarrow{ }^{5} \mathrm{I}_{8}$ and ${ }^{5} \mathrm{I}_{7} \rightarrow{ }^{5} \mathrm{I}_{8}$ respectively $[29,35,44-46]$. Among all the emission bands, the most intense sharpest emission band is at 648 $\mathrm{nm}$ which is due to the ${ }^{5} \mathrm{~F}_{5} \rightarrow{ }^{5} \mathrm{I}_{8}$ transition so that the HoMOF complex structure emits strong red light.

\subsubsection{Energy Transfer Mechanism}

The direct excitation of lanthanide ions is nearly impossible. The reason for this phenomena is that the $\mathrm{f}$ $\mathrm{f}$ transitions are prohibited due to parity selection rules. Therefore, the lanthanide complexes containing organic ligands absorbs the light in the UV region can transfer the energy through the ligand to the lanthanide ions via antenna effect $[35,46,47]$.

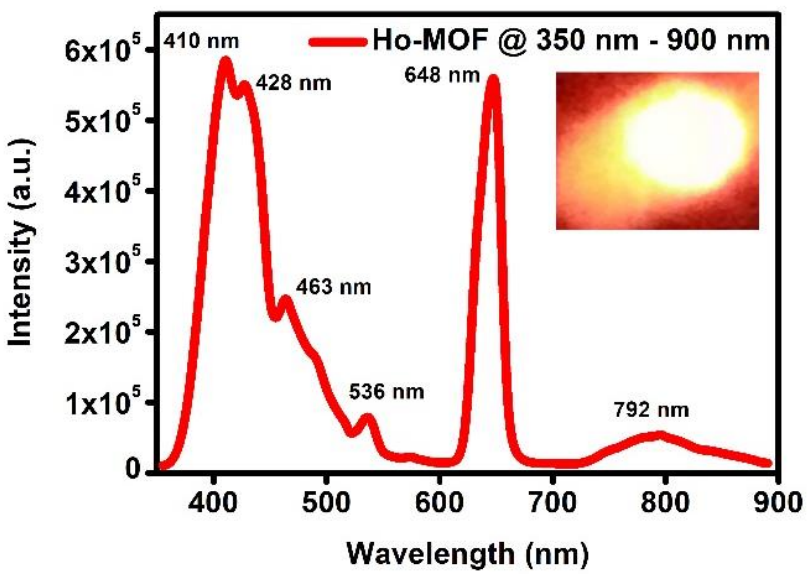

Figure 6. PL spectrum of the Ho-MOF complex in the $350-900 \mathrm{~nm}$ region under the excitation at $349 \mathrm{~nm}$ at room temperature. The upper right picture in the figure is a photoluminescent image of Ho-MOF while excited at $349 \mathrm{~nm}$

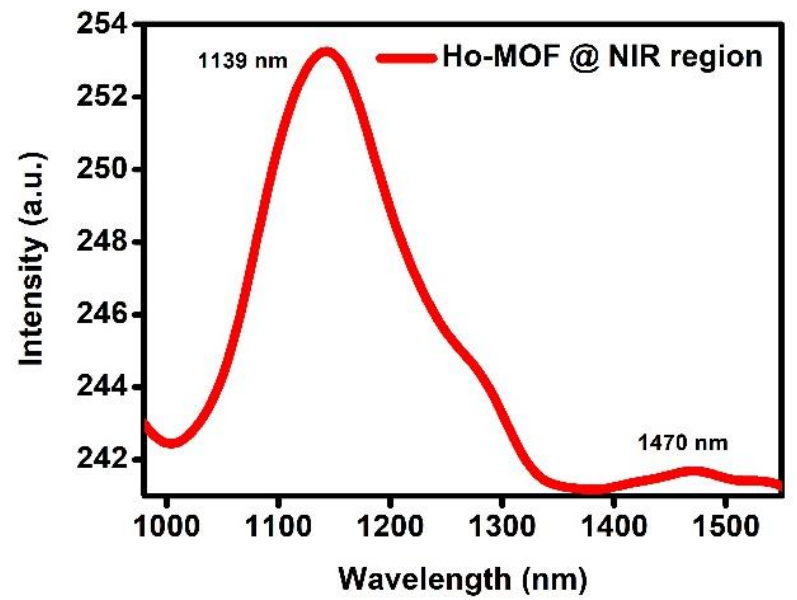

Figure 7. PL spectrum of the Ho-MOF complex in the NIR under the excitation at $349 \mathrm{~nm}$ at room temperature.

Fig. 8. represents the energy level diagram and energy transfer mechanism for $\mathrm{Ho}^{3+}$. Three step takes place for the sensitization. The first one is the ligands absorb the energy and are excited to the singlet $\left(\mathrm{S}_{1}\right)$ excited state. The second step is that the energy of this level is transferred to its triplet $\left(\mathrm{T}_{1}\right)$ level via intersystem crossing (ISC) as indicated in Fig. 8. The last step for this whole sensitization process is that the energy is transferred to the $4 \mathrm{f}$ levels of the $\mathrm{Ln}^{+3}$ ions.

According to Dexter's theory, the energy difference between the excited energy levels of the ligand and the triplet state of the $\mathrm{Ln}^{+3}$ ions play a key role in efficient energy transfer $[46,48]$. If the energy difference between these two states is too high, the overlapping of the triplet energy state of the ligand and $\mathrm{Ln}^{+3}$ ions will decrease and the energy transfer will drop sharply. If the difference between the triplet energy state is too small, then the transfer process of the ligand from lanthanide ions will starts. As a result, in our work, the energy transfers from the ligand to $\mathrm{Ho}^{+3}$ has been done effectively. 


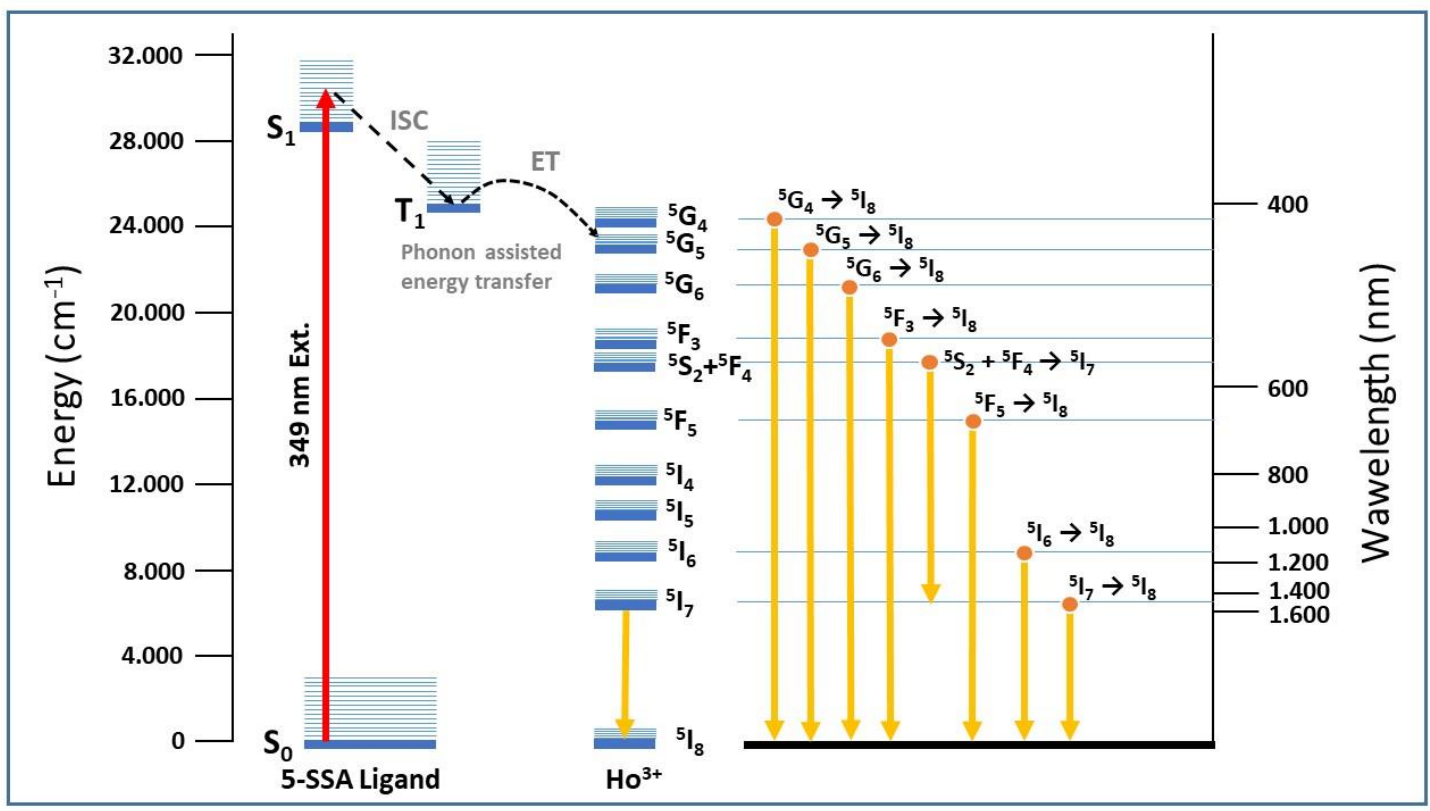

Figure 8. The schematic diagram of the sensitization of $\mathrm{Ho}^{3+}$ via intra-4f transition by the 5-SSA organic ligand

\section{Conclusion}

The new $\mathrm{Ho}^{+3}$ based metal-organic frameworks has been synthesized using 5-SSA organic linker by hydrothermal method. Powder XRD, FT-IR, UV-Vis Spectra has been done for the structural characterization of the Ho-MOF complex. The whole analyses show that PXRD, FT-IR and UV-Vis spectra of the Ho-MOF complex are in good agreement with the literature. Besides those analyses, the luminescence properties of the 5-SSA ligand and the Ho-MOF complex have been investigated under the excitation $349 \mathrm{~nm}$ at room temperature in the UV visible and NIR region and the energy transfer mechanism from 5-SSA ligand to the $\mathrm{Ho}^{+3}$ ion is investigated in detail. The PL measurements show that Ho-MOF complex exhibited several characteristic emissions of the $\mathrm{Ho}^{+3}$ ion in the UVVisible and NIR region and emits strong red light which is attributed to the $\mathrm{f}-\mathrm{f}$ electronic transitions. We may conclude that the energy transfers from the 5-SSA ligand to the $\mathrm{Ho}^{+3}$ ion have been done more effectively a via antenna effect. The excellent luminescent performances make this compound very good candidate for efficient luminescence materials.

\section{Acknowledgment}

The author is grateful to the Research Funds of Muğla Sıtkı Koçman University (BAP-16/052 and BAP-18/010) for the financial support, and Dr. M. Burak ÇOBAN, Balikesir University, Science and Technology Application have been taken for and Research Center (BUBTAM) for the Photoluminescence Spectrometer and to Dr. Hülya Kara SUBAŞAT and Dr. Uğur ERKARSLAN for their helpful and constructive suggestions.

\section{References}

[1] Wang, Z., Luo, X., Yun, R., Wang, Z., Huang, L., Hang, C., et al., "Highly Selective Carbon Dioxide Capture and Cooperative Catalysis of a Water-Stable
Acylamide-Functionalized Metal- Organic Framework", European Journal of Inorganic Chemistry, 2018, 1309-1314, 2018.

[2] Qiu, J., Zhang, X., Feng, Y., Zhang, X., Wang, H., and Yao, J., "Modified metal-organic frameworks as photocatalysts", Applied Catalysis B: Enviromental, 231, 317-342, 2018.

[3] Yahsi, Y., Ozbek, H., Aygün, M., and Kara, H., "Crystal structure and photoluminescence properties of a new CdII coordination polymer catena- poly[bis[4bromo-2-(\{[2-(pyrrolidin-1-yl)ethyl]imino\}methyl)phenolato-j3N,N000,0]di-l3chlorido- di-l2-chlorido-bis(methanolj0)tricadmium(II)]", Acta Crystallographica Section C Structural Chemistry, C72, 426-431, 2016.

[4] Li, W., Guo, Y., and Zhang, W., "A porous $\mathrm{Cu}$ ( II ) metal-organic framework: Synthesis, crystal structure and gas adsorption properties", Journal of Molecular Structure, 1143, 20-22, 2017.

[5] Zhou, H., Liu, B., Wang, H., Hou, L., Zhang, W., and Wang, Y., "Construction of Highly Porous Pillared Metal - Organic Frameworks: Rational Synthesis, Structure, and Gas Sorption Properties", Inorganic Chemistry, 56, 9147-9155, 2017.

[6] Nevruzoglu, V., Demir, S., Karaca, G., Tomakin, M., Bilgin, N., and Yılmaz, F., "Improving the Stability of Solar Cells Using Metal-Organic Frameworks", Journal of Materials Chemistry A, 4, 7930-7935, 2016.

[7] He, Y., Krishna, R., and Chen, B., "Metal-organic frameworks with potential for energy-efficient adsorptive separation of light hydrocarbons", Energy \& Environmental Science, 5, 9107-9120, 2012.

[8] Li, S., and $\mathrm{Xu}, \mathrm{Q} .$, "Metal-organic frameworks as platforms for clean energy", Energy \& 
Environmental Science, 6, 1656-1683, 2013.

[9] Vikrant, K., Kumar, V., Kim, K., and Kukkar, D., "Metal-organic frameworks (MOFs): potential and challenges for capture and abatement of ammonia", Journal of Materials Chemistry A, 5, 22877-22896, 2017.

[10] Gunatilleke, W. D. C. B., Wei, K., Niu, Z., Wojtas, L., Nolas, G., and Ma, S., "Thermal conductivity of a perovskite-type metal-organic framework crystal", Dalton Transactions, 46, 13342-13344, 2017.

[11] Acar, Y., "Photoluminescence Properties of Gd(III) and Ce(III) Lanthanide Based Metal Organic Frameworks", Mühendislik Anadolu University Journal of Science and Technology A-Applied Sciences and Engineering, 17, 754-765, 2016.

[12] Dönmez, A., Erkarslan, U., and Karadeniz, Ş., "[Eu(1,2,4-BTC)], (1,2,4-BTC=1,2,4- benzen trikarboksilik asit) koordinasyon polimerinin kristal yapı ve optik özelliklerinin araştırılması", Journal of Balıkesir Inst. Sci. Technoogy, 19, 44-49, 2017.

[13] Dönmez, A., Erkarslan, U., and Karadeniz, Ş., "Evropiyum içeren lüminesans özelliği gösteren metal- organik malzemelerin üretimi ve yapılarının araştırılması", Journal of Balıkesir Inst. Sci. Technoogy, 19, 64-69, 2017.

[14] Su, S., Wang, S., Song, X., Song, S., Qin, C., Zhu, M., et al., "Syntheses, structures, photoluminescence, and magnetic properties of $(3,6)$-and 4-connected lanthanide metal-organic frameworks with a semirigid tricarboxylate ligand", Dalton Transactions, 41, 4772-4780, 2012.

[15] Zhou, W., Wu, Y., Zhou, Z., Qin, Z., Ye, X., Tian, F., et al., "Construction of a series of lanthanide metal organic frameworks ( Ln-MOFs ) based on a new symmetrical penta-aromatic carboxylate strut: Structure , luminescent and magnetic properties", Inorganica Chimica Acta, 453, 757-763, 2016.

[16] Luo, L.-L., Qu, X.-L., Li, Z., Li, X., and Sun, H.-L., "Isostructural Lanthanide-Based Metal-Organic Frameworks: Structure, Photoluminescence and Magnetic Property", Dalton Transactions, Online, 111, 2017.

[17] Zhang, H., Peng, Y., Shan, X., Tian, C., and Du, S., "Lanthanide metal organic frameworks based on octahedral secondary building units: Structural, luminescent, and magnetic properties", Inorganic Chemistry Communications, 14, 1165-1169, 2011.

[18] Rodenas, T., Luz, I., Prieto, G., Seoane, B., Miro, H., Corma, A., et al., "Metal - organic framework nanosheets in polymer composite materials for gas separation", Nature Materials, 14, 48-55, 2015.

[19] Xia, W., Mahmood, A., Zou, R., and Xu, Q., "MetalOrganic Frameworks and their derived nanostructures for Electrochemical Energy Storage and Conversion", Energy \& Environmental Science, 8, 1837-1866, 2015.
[20] Oylumluoglu, G., "4,4- bipiridin ve 2-amino-1,4benzendikarboksilik asit tabanlı yeni bileşiğin sentezlenmesi ve hidrojen bağlı 3D polimerik yapısı", Journal of Balıkesir Inst. Sci. Technoogy, Online, 1-7, 2018.

[21] Sehimi, H., and Zid, M. F., "A novel Mn(II) oxalatobridged 2D coordination polymer: synthesis, crystal structure, spectroscopic, thermal and magnetic properties", Journal of Chemical Sciences, 130, 1-9, 2018.

[22] Shin Won, J., Jeong, A. R., Jeoung, S., Moon, H. R., Komatsumaru, Y., Hayami, S., et al., "Threedimensional iron(II) porous coordination polymer exhibiting carbon dioxide-dependent spin crossover", Chemical Communications, 54, 42624265, 2018.

[23] Davarcl, D., "Design and construction of onedimensional coordination polymers based on the dispiro-dipyridyloxy-cyclotriphosphazene ligand", Polyhedron, 146, 99-107, 2018.

[24] Dong, Y., Layland, R. C., Smith, M. D., Pschirer, N. G., Bunz, U. H. F., Loye, H., et al., "Syntheses and Characterizations of One-Dimensional Coordination Polymers Generated from Cadmium Nitrate and Bipyridine Ligands", Inorganic Chemistry, 38, 30563060, 1999.

[25] Zhao, H., Qu, Z., Ye, H., and Xiong, R., "In situ hydrothermal synthesis of tetrazole coordination polymers with interesting physical properties", Chemical Society Reviews, 37, 84-100, 2008.

[26] Yaghi, O. M., and Hailian, L., "Hydrothermal Synthesis of a Metal-Organic Framework Containing Large Rectangular Channels", Journal of American Chemical Society, 117, 10401-10402, 1995.

[27] Qi, Y., Luo, F., Che, Y., and Zheng, J., "Hydrothermal Synthesis of Metal - Organic Frameworks Based on Aromatic Polycarboxylate and Flexible Bis (imidazole ) Ligand", Crystal Growth \& Design, 8, 606-611, 2008.

[28] Oylumluoglu, G., Burak, M., Kocak, C., Aygun, M., and Kara, H., "2-and 1-D coordination polymers of Dy ( III ) and Ho ( III ) with near infrared and visible luminescence by ef fi cient charge-transfer antenna ligand", Journal of Molecular Structure, 1146, 356364, 2017.

[29] Coban, M. B., Erkarslan, U., Oylumluoglu, G., Aygun, M., and Kara, H., "Hydrothermal synthesis , crystal structure and Photoluminescent properties; 3D Holmium ( III ) coordination polymer", Inorganica Chimica Acta, 447, 87-91, 2016.

[30] Cosquer, G., Morimoto, M., Irie, M., Fetoh, A., Breedlove, B. K., and Yamashita, M., "Photo-control of the magnetic properties of Dy(III) and Ho(III) homometal coordination polymers bridged by a diarylethene ligand", Dalton Transactions, 44, 5996-6002, 2015.

[31] Li, T., and Xia, J., "Synthesis and Crystal Structure of 
a Novel Ho ( III ) Coordination Polymer with Oxalic Acid", Advanced Materials Research, 873, 697-700, 2014.

[32] Marques, L. F., Correa, C. C., Ribeiro, S. J. L., Molíria, V., Diogo, J., Dutra, L., et al., "Synthesis , structural characterization, luminescent properties and theoretical study of three novel lanthanide metalorganic frameworks of Ho ( III ), Gd ( III ) and Eu ( III ) with 2 , 5-thiophenedicarboxylate anion", Journal of Solid State Chemistry, 227, 68-78, 2015.

[33] Zhang, Y., and Zheng, J., "Three Ln ( III ) -2 , 3 , 5trichlorobenzoate coordination polymers ( $\mathrm{Ln}=\mathrm{Tb}$, Ho and Er ): Syntheses, structures and magnetic properties", Inorganic Chemistry Communications, 59, 21-24, 2015.

[34] Li, X., Lu, Y., Bing, Y., Zha, M., Li, X., Lu, Y., et al., "Synthesis , Photoluminescent, and Magnetic Properties of Two Lanthanide Sulfosalicylate Complexes Two Lanthanide Sulfosalicylate Complexes", Synthesis and Reactivity in Inorganic, Metal-Organic, and Nano-Metal Chemistry, 3174, 698-704, 2012.

[35] Coban, M. B., Amjad, A., Aygun, M., and Kara, H., "Sensitization of Ho III and Sm III luminescence by efficient energy transfer from antenna ligands: Magnetic, visible and NIR photoluminescence properties of Gd III , Ho III and Sm III coordination polymers", Inorganica Chimica Acta, 455, 25-33, 2017.

[36] Xiao, H., Zheng, Y., Liang, X., Zuo, J., and You, X., "Hydrothermal synthesis, crystal structures, and luminescent properties of two lanthanide ( III ) complexes containing 2-sulfoterephthalate", Journal of Molecular Structure, 888, 55-61, 2008.

[37] Zhang, L., and Zhu, L., "Influence of neutral amine ligands on the network assembly of lead ( II ) 4sulfobenzoate complexes", Journal of Molecular Structure, 873, 61-68, 2008.

[38] Liu, Q., and Xu, L., "Novel Structure Evolution of Lanthanide - SIP Coordination Polymers ( NaH 2 SIP = 5-Sulfoisophthalic Acid Monosodium Salt ) from a 1D Chain to a 3D Network as a Consequence of the Lanthanide Contraction Effect", European Journal of Inorganic Chemistry, 2005, 3458-3466, 2005.

[39] Sun, H.-Y., Huang, C.-H., Jin, X.-L., and Xu, G.-X., "The Synthesis, Crystal Structure and Synergistic
Florescence Effect of a Heteronuclear Lanthanide Complex (HLC)", Polyhedron, 14, 1201-1206, 1995.

[40] Li, X., Xie, Z., Lin, J., and Cao, R., "Lanthanide-organic frameworks constructed from multi-functional ligands: Syntheses, structures, near-infrared and visible photoluminescence properties", Journal of Solid State Chemistry, 182, 2290-2297, 2009.

[41] Coban, M. B., "Synthesis and photophysical properties of new Eu ( III ) complex", Journal of Balıkesir Inst. Sci. Technoogy, 19, 7-15, 2017.

[42] Zhou, X., Zhao, X., Wang, Y., Wu, B., Shen, J., Li, L., et al., "Eu ( III ) and Tb ( III ) Complexes with the Nonsteroidal Anti- In fl ammatory Drug Carprofen : Synthesis , Crystal Structure, and Photophysical Properties", Inorganic Chemistry, 53, 12275-12282, 2014.

[43] Feng, X., Feng, Y., Chen, J. J., Ng, S., Wang, L., and Guo, J., "Reticular three-dimensional 3d-4f frameworks constructed through substituted imidazoledicarboxylate: syntheses, luminescence and magnetic properties study", Dalton Transactions, 44, 804, 2015.

[44] Łyszczek, R., and Mazur, L., "Polynuclear complexes constructed by lanthanides and pyridine-3, 5dicarboxylate ligand: Structures, thermal and luminescent properties", Polyhedron, 41, 7-19, 2012.

[45] Dang, S., Yu, J., Wang, X., Sun, L., Deng, R., and Feng, J., "NIR-luminescence from ternary lanthanide [ Ho III , Pr III and Tm III ] complexes with 1-(2naphthyl)-4,4,4-trifluoro-1,3-butanedionate", Journal of Luminescence, 131, 1857-1863, 2011.

[46] Dang, S., Sun, L., Zhang, H., Guo, X., Li, Z., Feng, J., et al., "Near-Infrared Luminescence from Sol - Gel Materials Doped with Holmium ( III) and Thulium ( III ) Complexes", Journal of Physics and Chemistry of Solids, 112, 13240-13247, 2008.

[47] Sabbatinia, N., Mecatia, A., Guardiglia, M., Balzania, V., and Lehn, J., "Lanthanide luminescence in supramolecular species", Journal of Luminescence, 49, 463-468, 1991.

[48] Dexter, D. L., "A Theory of Sensitized Luminescence in Solids Articles you may be interested in A Theory of Sensitized Luminescence in Solids", The Journal of Chemical Physics, 21, 836-850, 1953. 